\title{
Elena Isabelle Tamba, Povestea unor locuri. Monografia toponimică a comunei Filipești, județul Bacău, Editura Universităţii „Alexandru Ioan Cuza”, Iași, 2018, 234 p.
}

\author{
Daniela Butnaru* \\ “A. Philippide” Institute of Romanian Philology, Str. Th. Codrescu 2, 700481 Iaşi, România
}

This volume is, as the subtitle suggests, a monograph dedicated to toponymy, belonging to a whole series of works of great interest for both the specialists in the field and the inhabitants of the village of. Her passion for the science that studies names of places, confessed by the author in the very first pages of this volume, has led her to carry out in-depth research in this respect. Thus, the material processed and analyzed throughout the pages of this research was collected by Elena Isabelle Tamba both during the toponymic surveys she conducted in the villages belonging to Filipești, and from novel documents, either kept in archives or published in various geographical and historical volumes, monographs, maps etc. The book includes a Foreword, signed by the author, three large chapters, I. Introducere [Introduction] (p. 11-105), II. Monografia toponimică [Toponymic Monograph] (p. 107-148) și III. Dicționar toponimic al comunei Filipești, județul Bacău [Toponymic dictionary of Filipești village, the county of Bacău] (p. 149-196), a few pages of Conclusions, Bibliography, and 24 annexes.

Although most of this work is dedicated to the presentation of major and minor toponymy in the researched area, there is plenty of information on the history and geography of the place, along with rich data regarding the social and economic background of the area and the land owners, all in close connection with the onomastic material. Since this work was intended for the general public, as well, the author generously included quite detailed presentations of agrarian reforms that led to ownership (which, in turn, led to the appearance or disappearance of certain toponyms), of the administrative evolution of the villages included in the commune of Filipești, as well as some encyclopaedic information.

The subchapter entitled Cadrul istoric [Historical Framework] comprises two large sections,
Atestările satelor actuale [Attestation of the presentday villages] and Atestările satelor dispărute [Attestation of the disappeared villages] (p. 41-104), where the author chose to reproduce, from the documents she researched, fragments mentioning the names of villages that were part of the commune of Filipești. There are cases in which the documents she quotes no not bring new information, as the names of places she provides share the same form; however, some versions attest variants of the same name (for instance, for the village of Hîrlești, the author recovers, from various documents, the names Herlești, Hîrliaşti, Hărlești, Hărlicești, p. 69). Since these documents deal with neighbouring villages, a document is likely to mention several localities and some quotations are inevitably repeated, being rendered for each of the villages discussed in this section. Nevertheless, this approach facilitates the understanding of the history of each particular village with its succession of owners, events from the past and description of various settlements, identified in the work of Hora von Otzellowitz (1790) or in Marele dictionar geografic al României (1898-1902).

The chapter entitled Monografia toponimică [Toponymic Monograph] starts by presenting the methodological aspects underlying the present research (the author presents the documentation stage aimed at identifying the sources in which the villages in the researched area are attested and at understanding the social-geographic specific features of the area, the criteria on which the selection of the informants was based, as well as the stages of the direct toponymic investigation). The subchapter entitled Studiu toponimic [Toponymic Study] presents the objective of the toponymic research, provides classifications of the toponyms according to the geographic objects they designate, their formation and syntactic structure, examples of

\footnotetext{
*Email address:d_butnaru@yahoo.com.
} 
synonyms (some specialists in onomastics consider that the most appropriate term in such cases is polyonym $^{1}$ ) and toponymic equivalents, a detailed analysis of the external syntax of names of places in the research area, as well as a presentation of the toponymic fields identified by the author in the Filipești area. Subchapter II.2.6, Originea toponimelor. Caracteristici dialectale [The origin of toponyms. Dialectal features] reveals that all the (social)geographical objectives on the territory researched by Elena Isabelle Tamba, except for Siret river, have Romanian names. The reader is provided with a list of entopic terms used by the inhabitants of the area, some of which can also be identified in the structure of the toponyms. Since there are also quite a few personal toponyms (which have the name of a person in their structure), a few pages dedicated to this anthroponymy would have been a very good idea, especially since the fragments extracted from the documents presented by the author contain many names of former owners. The main phonetic features specific to the area are exemplified, and in the list of entopic terms, some items are rendered in the phonetic version collected during the investigation (and not according to their literary form): bălătău, cioplaje, dărmătură de mal, hogas, hulboană, izitură, năsîpiște, ogaş, sîhoi.

With regard to "the inventory of entopic terms/entopic syntagms circulating in the area" from p. 143-148, , the author provides, for some items, explanations of their meanings that she received from the informants who participated in the research. The collection from the field of this type of appellatives is extremely important for observing the evolution of certain meanings or discovering new entopic terms which are not attested by dictionaries. However, there is still the risk that some authors have already mentioned $^{2}$, that some meanings provided by the interviewed participants actually be resemantizations or erroneous explanations that the speakers inferred from the aspect and name of a place. Batardou has, according to $\mathrm{MDA}^{3}$, the meaning of "provisory pier placed downstream various foundation works, bridge repair works, etc., in order to drain the field on which such works are executed" and, by extension, "the area thus determined". Consequently, it cannot mean "the place near the probe where mud is thrown". The term born "sign that delineated lands" is actuallybornă, mărişte "flooded place/area" and it probably represents a distortion of the appellative mîlişte "mîlitură/mud area" (MDA), occurring in this paper with the meaning "flooded place/area". The case of zăton "area with trees between Siret and Siretul Vechi" is most probably another instance of resemantization. We have not found attestations in the dictionaries of Romanian language ${ }^{4}$ for the entopic baraghin that apparently means, in the Filipești area, "valley temporarily filled with water that flows into Siret", for the appellative bişloagă "poor old little house" or the form bruienos ("area full of weeds"; see also loc bruienos), which is, most probably, the result of erroneous pronunciation.

Dicționarul toponimic [The Toponymic Dictionary] is elaborated according to the principles of the toponymic fields theory set out by the late professor and researcher Dragoș Moldovanu: the title-entry is represented by the name of a socio-geographical object (usually regarded by the locals as having a great importance for the respective area) from which other toponyms have subsequently formed by means of polarization and differentiation processes. The lexicographic entries are structured according to the following scheme: the title word in a literary form ${ }^{5}$, local pronunciation, the indication of the toponymic category, the definition indicating the denominated

${ }^{1}$ See Ion Toma, 101 nume de locuri, Editura Humanitas, București, 2015, p. 43 or Jean-Louis Vaxelaire, Les noms propres. Une analyse lexicologique et historique, Honoré Champion éditeur, Paris, 2005, p. 318, 422.

${ }^{2}$ See Dragoș Moldovanu, Un fenomen ignorat în anchetele dialectale: resemantizarea toponimelor (in "Anuar de ligvistică și istorie literară”, tome XXX, 1985, A, p. 23-39) or Mircea Ciubotaru, Terminologie geografică şi toponimie. Note critice (in "Anuar de ligvistică și istorie literară”, tome XLIV-XLVI, 2004-2006, p. 299-335).

${ }^{3}$ Mic dicționar academic, vol. I-II, Editura Univers Enciclopedic Gold, București, 2010. We chose this dictionary to render the meanings from because it is newly written and may contain more meanings for the discussed words than Dicționarul limbii române (DA), whose first volumes were edited at the beginning of the last century.

${ }^{4}$ Dicționarul limbii române, Tipografia Ziarului Universul, București, 1913-1948 și Editura Academiei, București, 1965-2010; Mic dicționar academic, vol. I, Editura Univers Enciclopedic Gold, București, 2010; Dicționar de arhaisme și regionalisme, vol. I, Editura Saeculum Vizual, București, 2002; Dicționarul entopic al limbii române, vol. I-II, Editura Universitaria, Craiova, 2009; Dicționar explicativ și etimologic de termeni geografici by Anatol Eremia, Editura Știința, Chișinău, 2006.

${ }^{5}$ Bălătăul, Coșere do not represent, however, the literary form. 
object and its location, further information wherever the case, the date of the first attestation identified by the author (usually stated in the case of oikonyms), other names of the denominated place, versions (in some cases) and explanations with regard to the origin of the names and the reasons they were chosen by the speakers. The toponymic dictionary comprises an impressing amount of names of places, collected from various documents or investigations conducted by Elena Isabelle Tamba in the commune of Filipești. As specified at page 109, toponyms from old documents whose referents could not be identified by either the editors or the author of the volume are not subject to analysis. The names of places included in the dictionary reflect all types of geographical objects in the area, as well as the results of human intervention: Balastiera, Balta Boilor, Băhnişoara, Canalul, În Cioate, Nimașul, Poiana de la Batardou, Sub Pădure, Tăul de la Bazin and the like. The property relationship is extremely well depicted, as many names preserve in their syntagmatic or periphrastic structure the names of current or former owners: Balais (from the name of the boyard C. Balaiș), La Ureche (reminder of a boyard named Ureche), Lavăr (from the name of the boyard A. Lawer, a former owner in the area), La Damian (because a family called Damian lives there), In Spini la Gheorghiță Crăciun ("there was the land of Ghiță Crăciun”), Galbeni (formed of the surname of a former owner, Giurgiu Galbenul), the Vasiliu fields remind of the boyard Gh. Vasiliu, the Racoviţă agricultural field once belonged to captain Ion Racoviță, etc.

In the following lines we would like to make a few recommendations regarding the dictionary and the organization of some lexicographic entries, in case the author wishes to re-edit the volume: it would be useful to provide references for all the toponyms processed within an entry, not only for the oikonym versions, so that they can be more easily identified in the dictionary body; the entries Pădurea Precista and Precista (= creek) should be considered together, as they are the result of a polarization process from the name of Precista monastery; the toponyms included at the title-words $D$ upa $\breve{S}$ Sat ${ }^{1,2}$ should be integrated in the toponymic fields of Boanța and Hirlesti, respectively; Poșta Filipești belongs to the field developed around the oikonym Filipești; Satul Vechi should be regarded as the result of a toponymic differentiation process from the oikonym Onişcani; equally by differentiation, this time from the hydronym Siret, was formed Siretul Vechi la Tuluc. The plural form of the word răzor might actually be the origin of the toponym Răzoalea.

This volume comprises very many bibliographic references, not only to edited works, but also to various documents or plans that can be found in archives (see, for instance, the notes on page 35), facilitating thus the work of those who would like to perform an in-depth analysis of various aspects related to the history of the place and the evolution of properties. It should be said that fortunately, for the villages belonging to the commune of Filipești numerous valuable documents were preserved, and the author has successfully identified them at the county offices of the Romanian National Archives in Bacău, Iași and Neamț.

We also note that the volume does not only present names of places that exist or existed in the researched area, but we also find out about a future toponym, chosen by the local administration representatives: Strada Radu Beligan (p. 25). The toponym is justified by the fact that the great Romanian actor was born in the village of Galbeni (p. 30), which is part of the commune studied in the monograph. Most probably, in the near future, the name Labirintul (or La Labirint), will also come up, due to the touristic arrangement consisting of the "greatest green labyrinth in the country, made of trees belonging to the Thuja Plicata species" (p. 30). The annexes at the end of the volume (fragments of estate plans, maps and documents regarding the researched area, along with a map of the commune that contains, besides the names of localities, 78 other toponyms) are extremely useful.

Due to the original material it contains, the rich information it provides and the rigorous structure of the research, we consider that this toponymic monograph is a significant contribution to the toponymic research regarding the commune of Filipești (consequently regarding Romanian toponymy, generally), providing valuable insights upon the history of the places and inhabitants of the area investigated by the researcher. This felicitous approach should be carried on, with equal competence, by other scholars. 